\title{
Effect of alternative hormones on the rootability of parkia biglobosa
}

\author{
Oluwagbenga Dunsin, Gabriel Ajiboye, Taiwo Adeyemo \\ Department of Crop \& Soil Sciences, Landmark University, Omu-Aran, Kwara-State. Nigeria \\ Corresponding authors email: dunsin.oluwagbenga@lmu.edu.ng
}

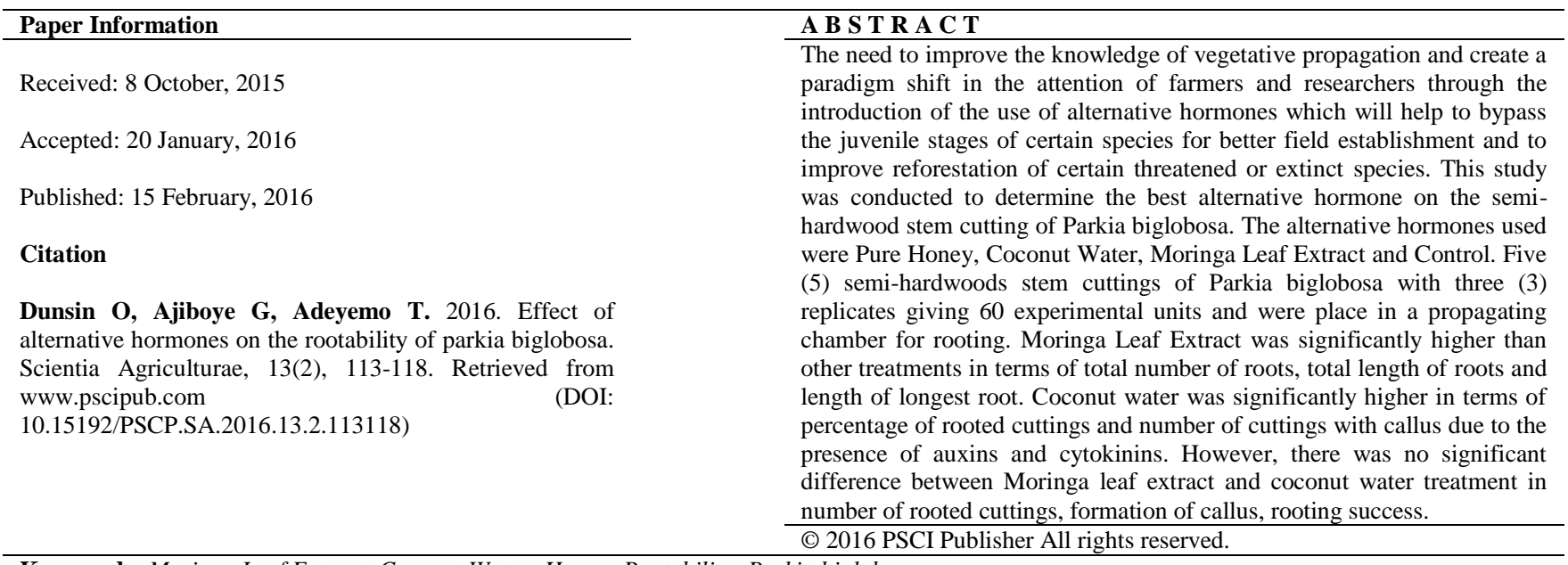

Key words: Moringa Leaf Extract; Coconut Water; Honey; Rootability; Parkia biglobosa.

\section{Introduction}

The existing economic and perennial trees like locust beans tree, cashew tree, shea butter tree etc., are ageing and fast disappearing, It is therefore imperative to intervene to save this important trees from extinction. Despite the ethnobotanical and socio-economic benefit of these indigenous perennial trees species, conscious efforts towards an organized population ecology and regeneration management of the wild population in Nigeria across the different agroecological zones remain very low compared to what had been reported in Ghana (Osei-Amaning, 1996). Hence the study on vegetative propagation is a preliminary and very important step in the conservation, domestication and regeneration of these trees such as Parkia biglobosa. Since the acquisition of natural rooting hormones like Indole-3-acetic acid (IAA) and Indole-3-butyric acid (IBA) is becoming difficult and also expensive, therefore there is the need to propagate with alternative rooting hormones that support rooting of cuttings.

A number of health hazards are now being associated with the consumption of excess table salt, seasoning, and other food condiments, for which nutritionist are now advocating the generous use of locust beans as a natural product of spicing soup and stew. Yet the agronomy potential of the tree crop has not been properly identified. Parkia biglobosa a perennial deciduous tree legume belongs to the family fabaceae (Alabi et al., 2005: Don, 2007) and sub-family mimosoideae, it is commonly referred to as the African locust bean tree. The plant was named after Mungo Park by Robert Brown in 1826 (Orwa et al., 2009). Parkia biglobosa as a common species of the parkland agro-forestry plays important roles such as food, wood production, supply of timber, firewood, pulp and fibre through fodder, gum, drugs, and dyes as well as restoration of soil fertility. Parkia biglobosa is also a common condiment in the food of African countries and it is peculiar for both its aesthetic and nutritive value with a proximate composition of $30.0 \%$ protein, $15.0 \%$ fat, $4.0 \%$ crude fiber and 49.0\% carbohydrate (Fetuga et. al., 1974; Campbell Platt, 1980; Odunfa, 1986).

The fruit is a pod, slightly indented between the seeds at maturity and the seeds are embedded in a yellowish, mealy, sweet tasting edible pulp (Aliero et. al., 2001). The seeds are used as flavouring and additives to soups and stews. It is also used in agroforestry because of its ability to fix atmospheric nitrogen in the soil.

Hormones are chemicals produced by plants that regulate the growth processes and the same are applied by horticulturist to promote growth and development of crops. They can be used to stimulate root development, control plant height in greenhouse investigation and also increase size of fruit. They are usually applied in small quantities which are measured in parts per million (ppm) and horticulturists use them to understand and manipulate plants for specific purposes (Whiting et al, 2014). Alternative hormones are natural materials that possess the ability to stimulate the rooting of 
cuttings, they are a suitable substitute to the synthetic hormones such as auxins, cytokinins, gibberellins which are essential and popular rooting hormones. Examples of alternative hormones used are honey, coconut water, willow tea, aspirin, moringa extract and saliva (Shield P., 2012. Carusetta S., 2014).

Parkia biglobosa grows mainly in the wild state and most of its trees have not been domesticated and are being ravaged by annual bush fire in the tropics thus inevitably facing extinction (Izquirdo and Roca, 1998). The inevitable consequence of this is the scarcity of its products, there have been no deliberate production of the tree despite the importance of its products notably because, it takes a long time for the trees to fruit and there is very little knowledge of silvicultural techniques of the tree. (Orwa et al. 2009). Therefore the aim of this study is to assess the effects of alternative hormones on the rootability and regeneration of Parkia biglobosa.

\section{Materials And Methods}

The experiments were carried out in a polypropagator rooting chamber constructed following a design as described by Leakey et al., (1990) at Landmark University Teaching and Research Farm Omu-aran, Kwara Screenhouse from February 2014 to April 2015. The study area is located at latitude $8^{0} 13{ }^{1} \mathrm{~N}$ and Longitude $5{ }^{0} 10{ }^{1} \mathrm{~S}$, with altitude of $506 \mathrm{~m}$ above sea level of the Guinea savannah zone of Nigeria.

The cuttings were taken from a vigorous and healthy Parkia biglobosa tree in Landmark University Farm area. Materials were taken from a single mother tree early in the morning. The cuttings were separated by a sterile secateur to prevent the xylem from being crushed, given it a very smooth surface and prevent microbial infection. The stem cuttings obtained were semi-hardwood cutting of uniform diameter and length of $15 \mathrm{~cm}$ in an angle of 45 degrees with at least 2 buds on each stem and all leaves were removed to reduce evaporation from the cuttings. All the cuttings were treated for 15 minutes in a solution of fungicide funguforce. Three types of alternative rooting hormones namely; Honey (Pure Honey), Coconut Water and Moringa Leaf Extract (MLE) were used. The stem cuttings were treated with the alternative hormones for 3 minutes and air dried for 5 minutes after each basal end treatments. The design of the experiment was a Randomized Complete Block Design (RCBD) where five cuttings of Parkia biglobosa were subjected to four treatments (control included) and replicated three times to give a total of 60 cuttings. At the end of the experiment, the following observations were made and data collected were; Number of rooted cuttings, Number of cuttings with callus, Number of cuttings with mortality, Total number of roots, Total root length of cuttings and Length of longest root of cuttings. The data collected was analysed using Analysis of Variance (ANOVA) and the means were separated using Least Significant Difference (LSD).

\section{Results And Discussion}

\section{The effect of alternative hormones treatment on the number of rooted cuttings}

In the case of rooted cuttings, the results indicated that there is a significant difference in the distributed cuttings of Parkia biglobosa at $5 \%$ probability. The experiment shows treatment with Coconut Water was significantly higher (3.667), than treatment with Moringa Leaf Extract, Honey, and control, (3.00, 2.00 \& 1.667 respectively) as shown in table 1. This can be supported by the work of Leakey, (2004) who noted that, the cuttings that have high level of auxins and cytokinins (Coconut Water and Moringa Leaf Extract) have higher percentage of cuttings that will root. The response was also confirmed by Yong et al., 2013 who showed that coconut water contains a content of cytokinins which helps to stimulate the growth of roots and shoots.

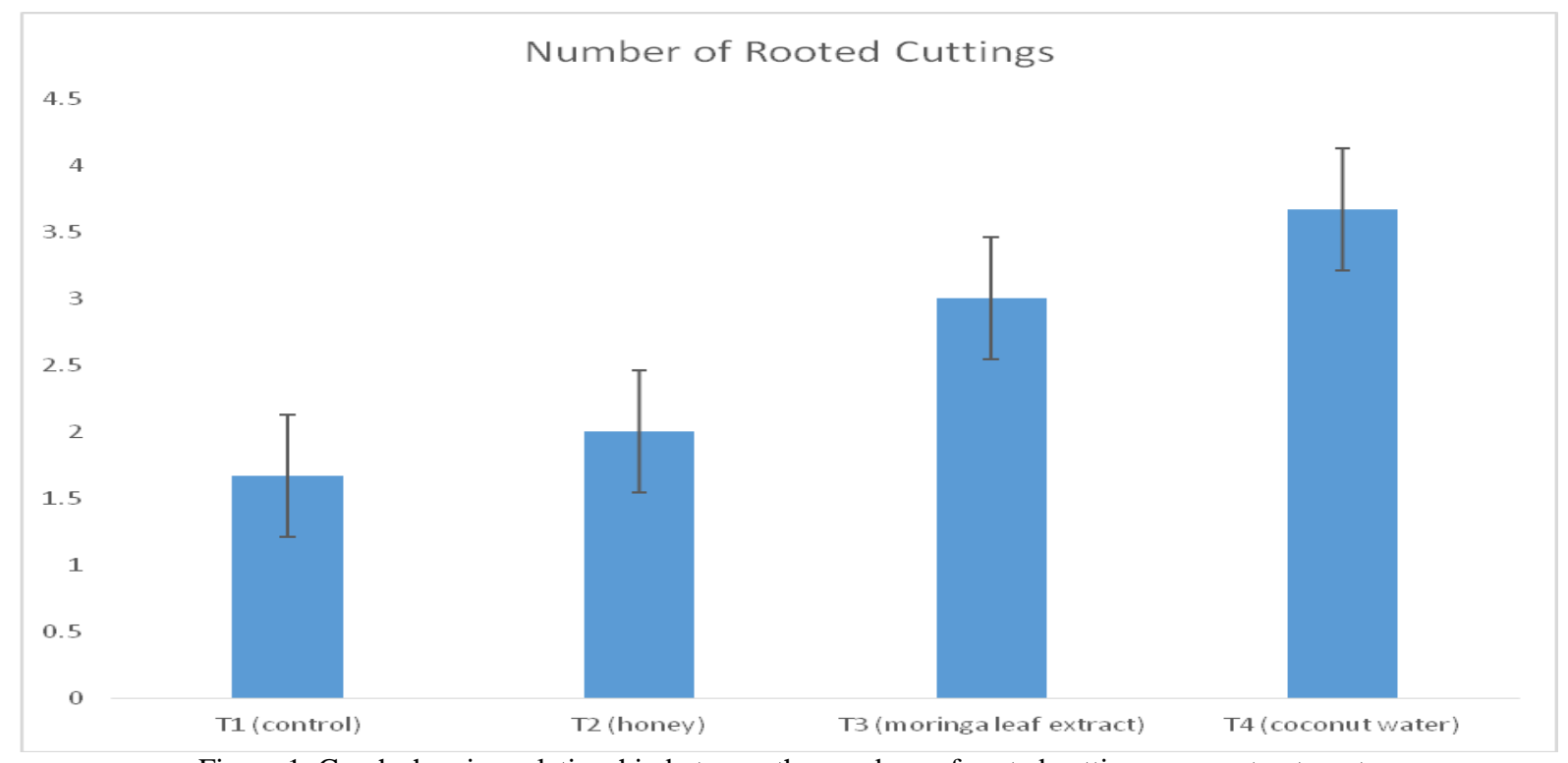

Figure 1. Graph showing relationship between the numbers of rooted cuttings among treatments 


\section{The effect of alternative hormones treatment on number of cuttings with callus}

The result as shown in Fig. 2 shows that there is significant difference amongst the treatments, with Coconut Water showing the highest percentage of callus formation as compared to the control. There was no significant difference between Coconut Water and Moringa Leaf Extract treatments. According to Yong et al, (2009.), it was reported that Coconut Water was widely used in the plant tissue culture industry for the production of callus.

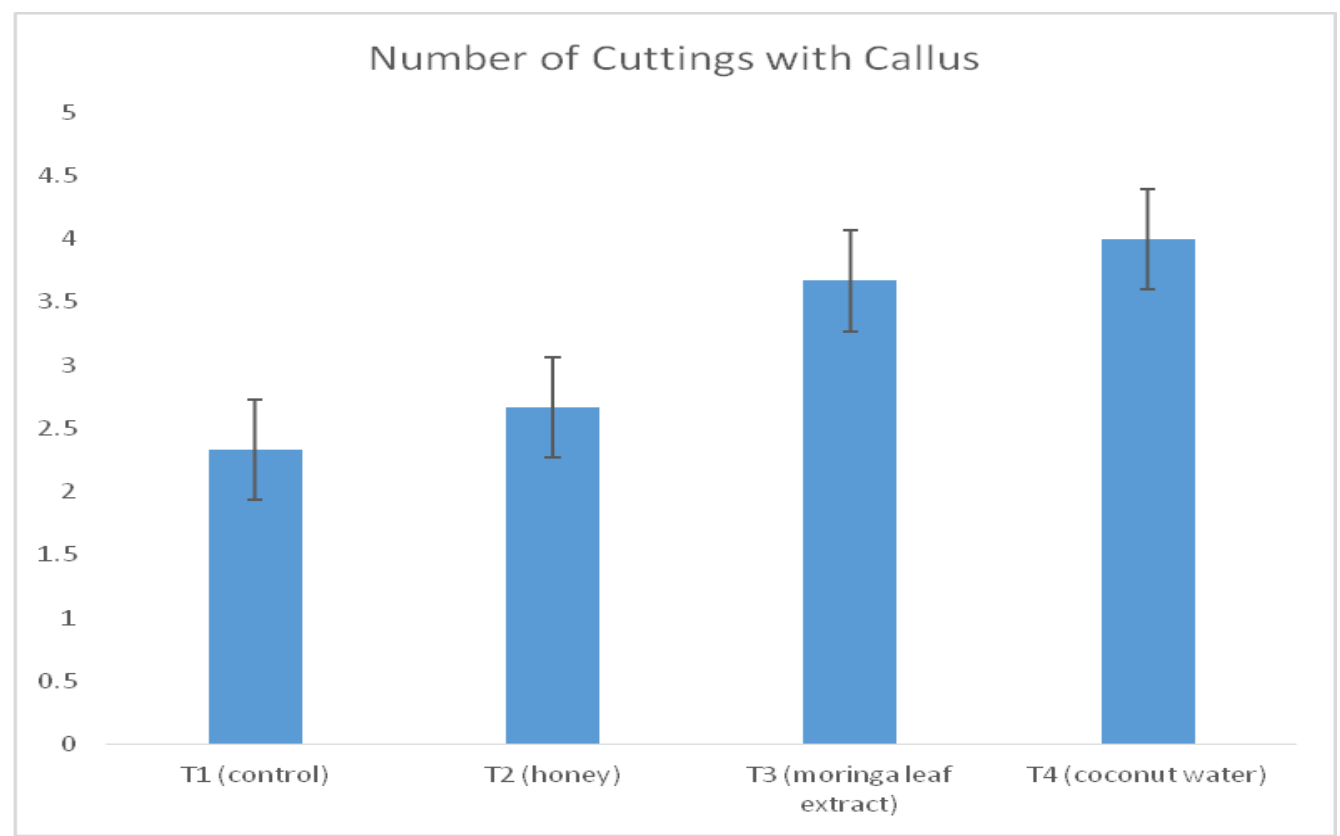

Figure 2. Graph showing the number of cuttings with callus among treatments

\section{The effect of alternative hormones treatment on number of cuttings with mortality}

The results showed that the control treatment has the highest level of mortality in cuttings as compared to treatment with moringa extract or coconut water. This indicated that cuttings treated with moringa leaf extract supported the survival of root cuttings as shown in Table 1. The high mortality rate in the control cuttings may be due to absence of rooting hormones like Auxins and cytokinins found in both Coconut Water and Moringa Leaf Extract.

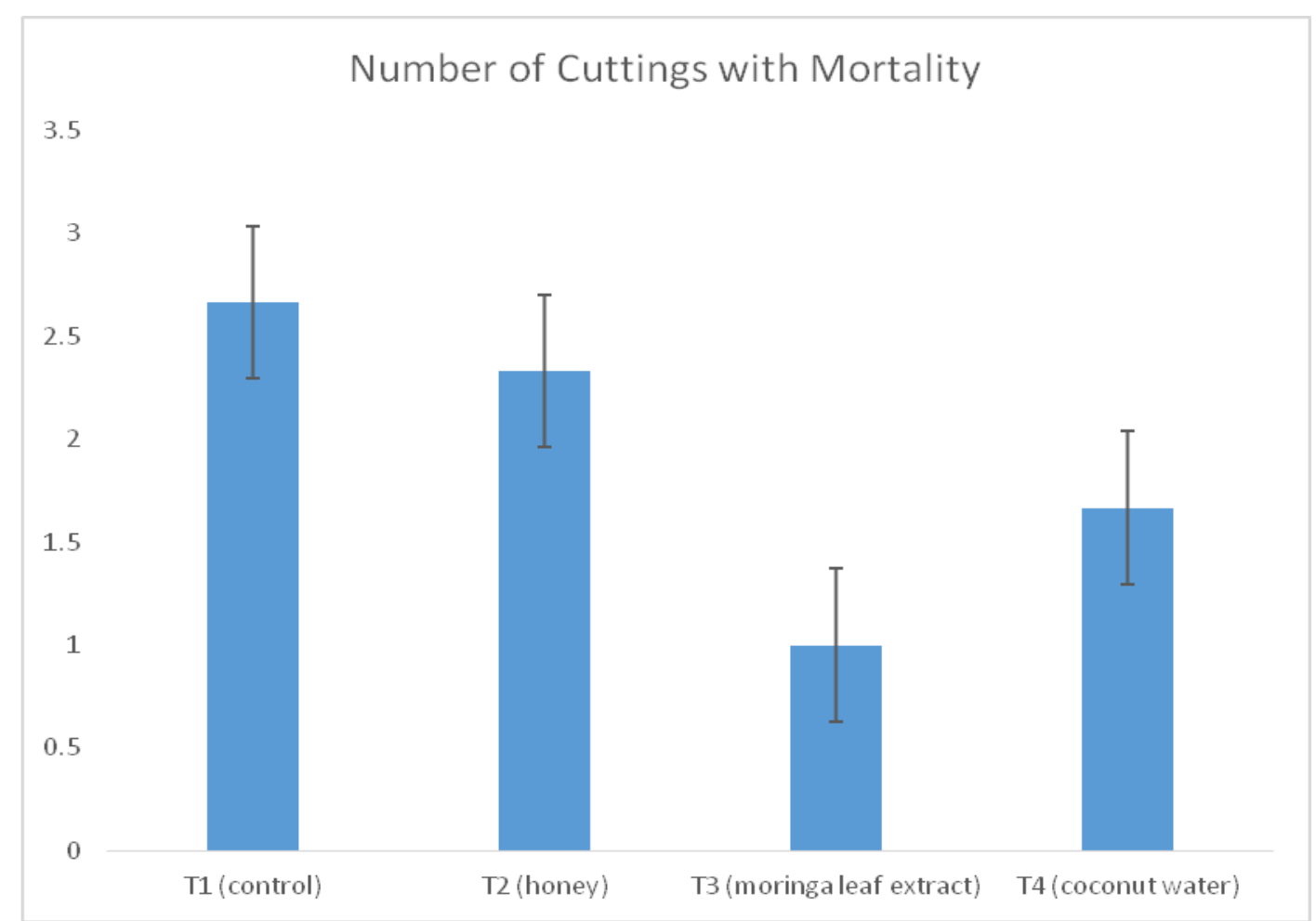

Figure 3. Graph showing the number of cuttings with mortality among treatments 
Table 1. Effect of alternative hormones treatment on number of rooted cuttings, callus formation and mortality of Parkia biglobosa semi-hardwood cuttings (day 28).

\begin{tabular}{lccc}
\hline Treatments & Number of Rooted Cuttings & $\begin{array}{l}\text { Number of Cuttings With } \\
\text { Callus }\end{array}$ & $\begin{array}{l}\text { Number of Cuttings With } \\
\text { Mortality }\end{array}$ \\
\hline T1 (control) & 1.667 & 2.333 & 2.667 \\
T2 (honey) & 2 & 2.667 & 2.333 \\
T3 (moringa leaf extract) & 3 & 3.667 & 1 \\
T4 (coconut water) & 3.667 & 4 & 1.667 \\
\hline
\end{tabular}

\section{The effect of alternative hormones treatment on total number of roots}

In the case of number of roots, the results indicated a significant difference in number of roots between the treatments. Moringa Leaf Extract has the highest values in number of roots followed by t Coconut Water (8.67 and 7.33 respectively).

The highest number of root observed in cuttings treated with Moringa Leaf Extract is due to the presence of Zeatin which is a component of Auxin found in the extract from moringa leaf that aid root elongation and formation as reported by Culver et al.,( 2012).

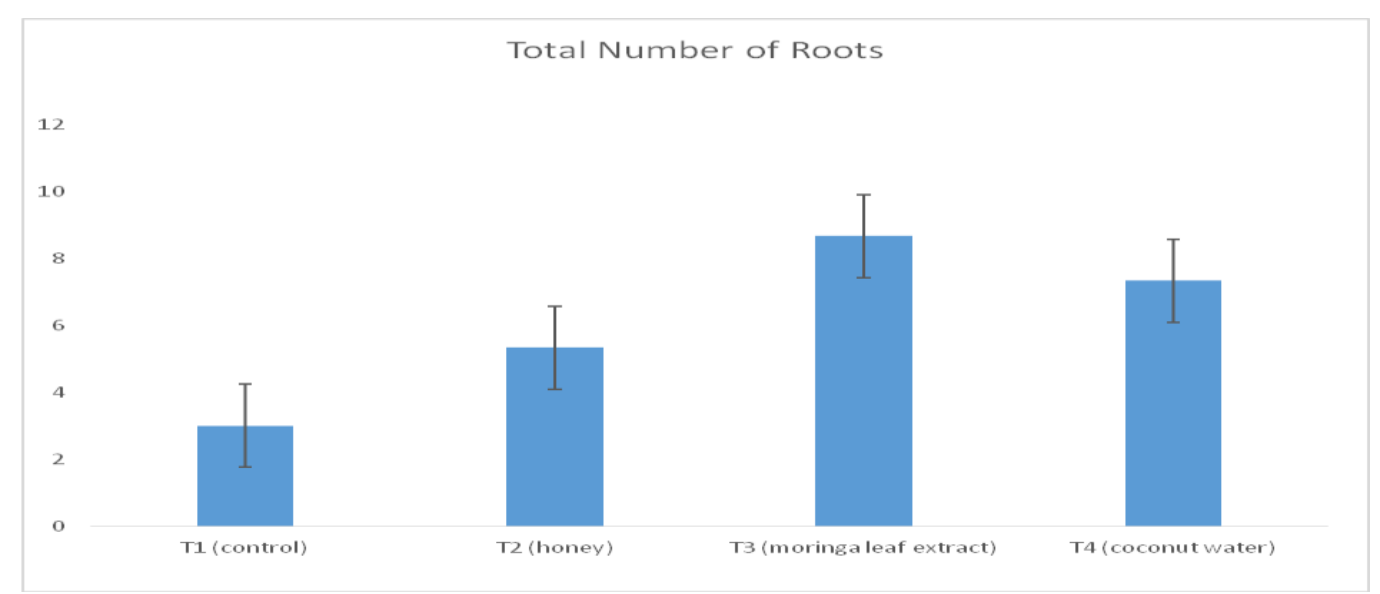

Figure 4. Graph showing the total number of roots of cuttings for all treatments

\section{The effect of alternative hormones treatment on total root length of cuttings}

In the case of total root length, (table 2) it was revealed that cuttings treated with Moringa Leaf Extract were the highest value (12.457), for total length of roots for all cutting, followed by treatment of coconut water (11.617). Although there was no significant difference between Moringa Leaf Extract and cuttings treated with Coconut Water, but these were significantly higher than Honey treatment and the control as shown in Fig. 7. These results confirm that rooting ability of Parkia biglobosa was sensitive to Moringa Leaf Extract Application due to the present of cytokinins in form of zeatin presence in moringa that stimulates cell division (Lateral Dominance).

\section{Total Root Length}
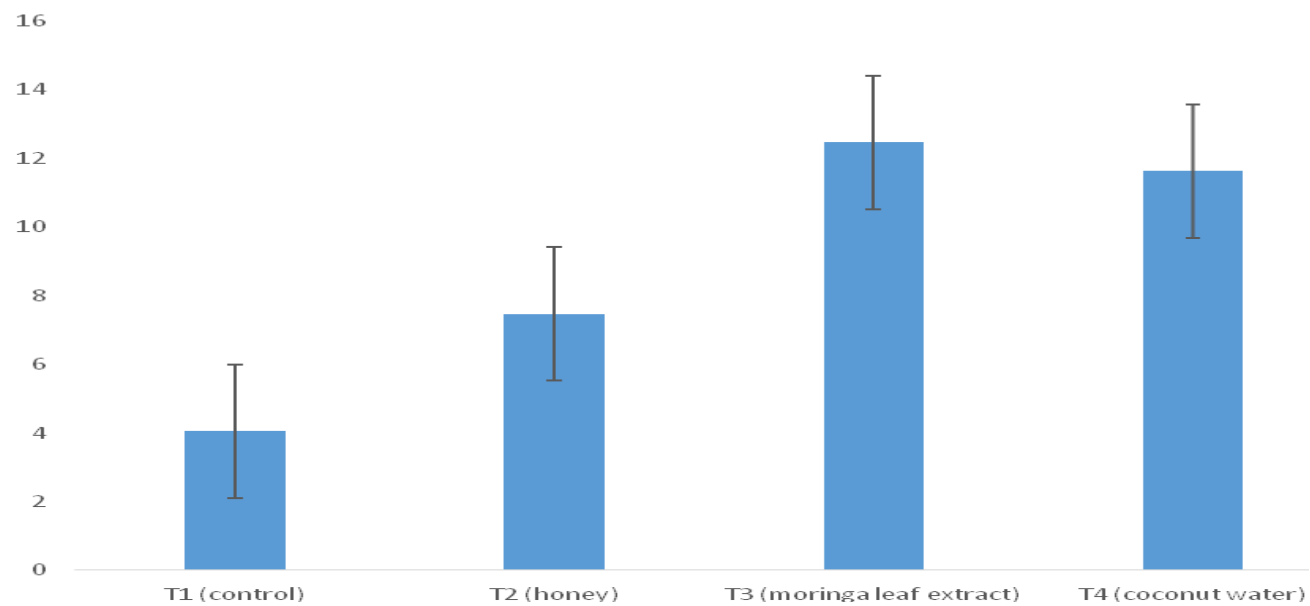

Figure 5. Graph showing the total length of roots of cuttings for all treatments 


\section{The effect of alternative hormones treatment on length of longest root of cuttings}

The result from Table. 2, shows a significant difference among the treatments with respect to length of longest root per cutting. Moringa Leaf Extract (1.493) has the longest root length per cutting compared to the control (1.4270).Coconut water (1.487) and treatment of honey (1.427) were not significantly different.

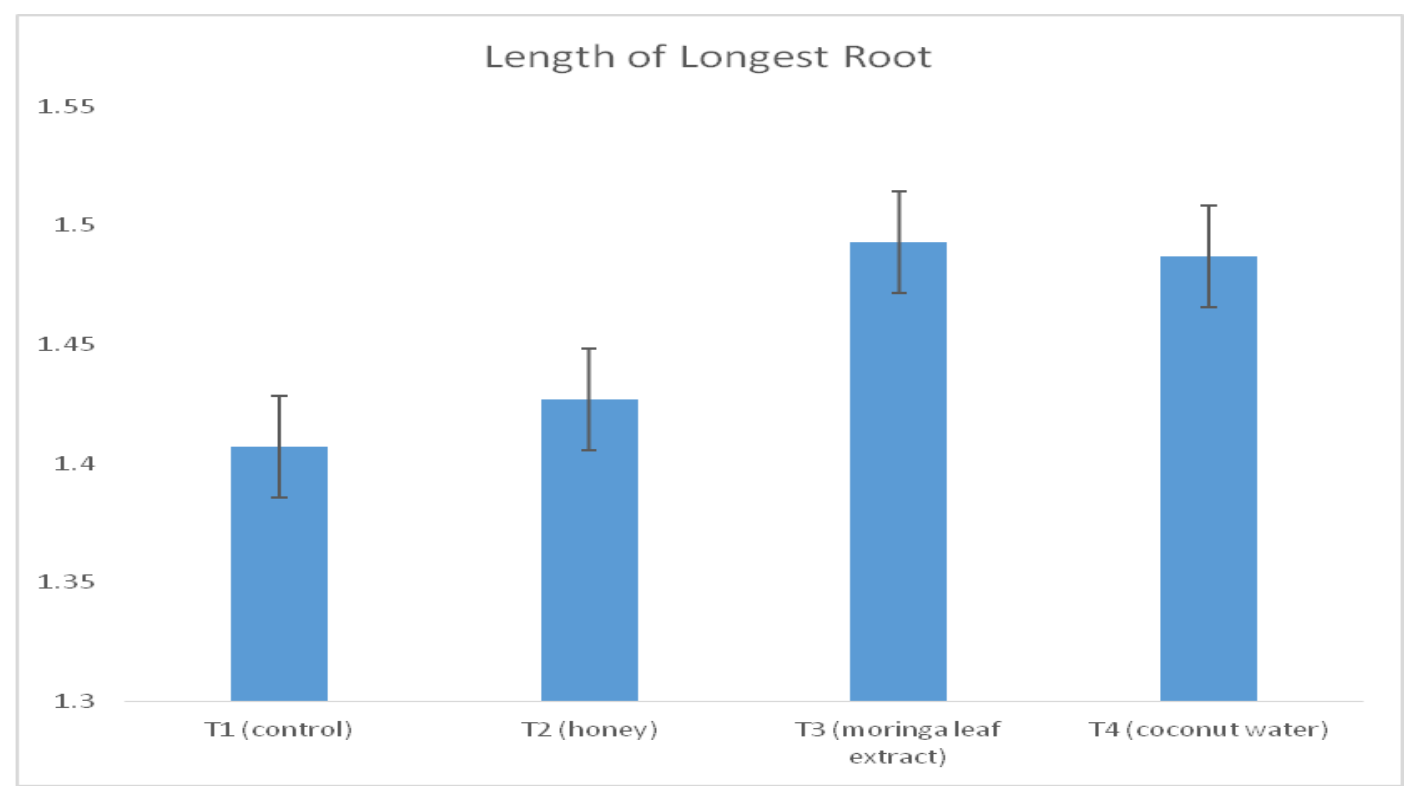

Figure 6. Graph showing the total length of longest root per cuttings for all treatments

Table 2. Effect of alternative hormones on total number of roots, total root length, and length of longest root per cutting of Parkia biglobosa semi-hardwood cuttings (day 28)

\begin{tabular}{llll}
\hline Treatments & Total Number of Roots & Total Root Length & Length of Longest Root \\
\hline T1 (control) & 3.00 & 4.047 & 1.407 \\
T2 (honey) & 5.333 & 7.470 & 1.427 \\
T3 (moringa leaf extract) & 8.667 & 12.457 & 1.493 \\
T4 (coconut water) & 7.333 & 11.617 & 1.487 \\
LSD & 3.2455 & 5.3428 & 0.0832 \\
\hline
\end{tabular}

\section{Conclusion And Recommendation}

The present study has revealed that the rooting ability of Parkia biglobosa proved successful indicating that the species shows good response to application of these alternative hormones. The experiment shows that Coconut water supports a higher rooting percentage over Moringa leaf extract (MLE) due to the presence of auxins and cytokinins (Yong et al., 2013) while Moringa Leaf Extract (MLE) which contains majorly cytokinins which is evident through the advantage it has over coconut water in total root length, length of longest root and total number of roots per cuttings due to higher content of cytokinins (especially zeatin). The research also show that both Moringa Leaf Extract and Coconut water support the rooting of semi-hardwood stem cuttings of Parkia biglobosa, of the two alternative hormones the best rooting hormone for successful vegetative propagation of semi-hardwood cuttings, Moringa Leaf Extract (MLE) shows better potential for root vigor due to its influence in producing greater number of root, longest length of roots per cutting and collectively root length.

Thus, rooting of stem cuttings of Parkia biglobosa with plant growth regulator presents a viable propagation system to be used in enrichment planting programmed of this important Tree crop in reduction propagation time via seedlings which is important for farmers because time constrain in sexual propagation via seeds and reduction in cost producing of plating materials through purchasing synthetic hormones since alternative hormone like Moringa Leaf Extract or coconut water is easier and cost effective

Further study should be done using the alternative hormones on the vegetative propagation of other permanent trees crop using other types of stem cuttings (hardwood and softwood).

\section{References}

Alabi DA, Akinsulire OR, Sanyaolu MA.2005. African Journal on Biotechnology, 4:812-815.

Aliero BL, Umaru MA, Suberu HA, Abubakar A .2001. A handbook of common plants in Northwestern Nigeria, Sokoto, Sokoto University Press, 130 p.

Campbell-Platt G.1980. African locust beans (Parkia spp) and its West African Fermented Food product, 'Dawadawa'. Ecological Food Nutrition. 9:123. Carusetta S.2014. Homemade Rooting Compound for Plants. Retrieved from http://homeguides.sfgate.com/homemade-rooting-compound-plants38260.html

Culver M, Tagwira F , Albert Z. Chiteka 2012. Effect of Moringa Extract on Growth and Yield of Tomato. Greener Journal of Agricultural Sciences ISSN: 2276-7770 Vol. 2 (5), pp. 207-211. 
Don G. 2007. Seed leaflet. Parkia biglobosa (Jack.). A tree species reference and selection guide. 1-4.

Fetuga BL, Babatunde GM, Oyenuga VA.1974. Protein quality of some unusual protein foodstuffs: Studies on the African locust beans (Parkia filiciodea Welv) Seed. Brit. J. Nutri. 32: 27-36.

Izquirdo J, Roca W .1998. Under-utilized Andean food crop: status and prospects of plant biotechnology for the conservation and sustainable agricultural use genetic resources. Acta Horticulturae 457:157-172.

Leakey RRB, Mesén JF, Tchoundjeu Z, Longman KA, Dick JMcP, Newton AC, Matin A, Grace J, Munro RC, Muthoka PN.1990. Low-technology techniques for the vegetative propagation of tropical trees. In: Rogers MT (ed): Commonwealth Forestry Review. Vol.69(1), pp.247-257. The Commonwealth Forestry Association (CFA)/Bocardo press, Oxford, UK. ISSN: 0010-3381. Available online: http://www.bodley.ox.ac.uk/users/millsr/isbes/ODLF/CFR69.pdf Access date [2010-04-06].

Leakey RRB.2004. Physiology of vegetative reproduction. In: Burley J, Evans J, and Youngquist JA (eds): Encyclopedia of Forest Sciences. Pp.16551668:2400. Elsevier, Oxford/Academic Press, London, UK. First edition, four volume set. ISBN-10: 0-12-145160-7. ISBN-13: 978-0-12145160-8.

Odunfa SA.1986. Dawadawa In: Legume based fermented of foods. Ed. N. R. Reddy, M.D. Pierson, D.K. Salunkhe. CRC Press Inc. Boca Raton, Florida.

Orwa C, Mutua A, Kindt R, Jamnadass R, Anthony S.2009. Agroforestry Database:a tree reference and selection guide version 4.0. 1. Retrieved November 26, 2014 from (http://www.worldagroforestry.org/sites/treedbs/treedatabases.asp).

Osei-Amaning E.1996. Management of Vitellaria paradoxa in Guinea savanna rangelands in Ghana. An Un-published Ph.D Thesis University of Wales, Bangor, 199pp

Shield P.2012.Three Organic Alternatives to Hormone Rooting Powder. Retrieved from http://montrouch-organic.over-blog.com/article-three-organicalternatives-to-hormone-rooting-powder-101172112.html

Whiting D, Roll M, Vickerman L.2014. Colorado Master Gardener Garden notes: Plant Growth Factors-Plant Hormones. Retrieved from http://www.ext.colostate.edu/mg/gardennotes/145.html

Yong WH Jean, Liya G, Yan Fei N, Swee NT.2009. The Chemical Composition and Biological Properties of Coconut (Cocos nucifera L.) Water. Natural Sciences and Science Education Academic Group, Nanyang Technological University. Molecules 2009, 14, 5144-5164; doi: 10.3390/molecules 14125144 .

Yong WH Jean, Liya G, Yan Fei N,d Swee NT.2013. The composition of plant growth regulators in coconut water. Parsons Laboratory, Department of Civil \& Environmental Engineering, MIT, Cambridge, MA 02139, USA 3Natural Sciences \& Science Education, Nanyang Technological University, Nanyang Walk, Singapore 637616.

Yusuf O, Rahji MAY .2012. The processing and preference for Locust Beans Products (Parkia biglobosa) in Lagos. Nigeria Journal of Biology, Agriculture and Healthcare. ISSN 2224-3208 (Paper), ISSN 2225-093X (Online), Vol 2, No.11, 2012: pp 1-2. 